\title{
Constructing Citizenship Without a Licence: The Struggle of Undocumented Immigrants in the USA for Livelihoods and Recognition ${ }^{1}$
}

\author{
FRAN ANSLEY \\ College of Law, University of Tennessee
}

\begin{abstract}
This article questions the meanings and expression of "citizenship" in the context of new Latina and Latino migration into the southeastern United States-a region long marked by legally policed racial systems and now experiencing the varied shocks of globalization. Focused on a legislative campaign that won access to a state-issued driver's licence for undocumented migrants in Tennessee in spring 2001, the article explores some of the tensions that emerged on the road to this unlikely victory and raises questions for the immigrants' rights movement in the US about the costs and gains that may follow from different ways of framing its demands. The dominant frame this particular campaign adopted was a pragmatic and politically acceptable call to improve traffic safety, one that reflected a conscious choice to downplay issues of rights, justice or global perspective. Yet the article also reports that the campaign in fact created and used opportunities for activists to raise issues related to migrant rights. It also made a dramatic, albeit temporary, improvement in the daily lives of migrants in the state. The article then sketches three citizenship norms that current struggles might prefigure. These three norms are: the full right to international mobility of human beings; the right to identity; and duties of citizenship in a globalizing world.
\end{abstract}

This article tells the story of a legislative campaign mounted by immigrants and their allies in Tennessee, a state in the southeastern USA that has experienced a dramatic new wave of low-wage labour migration from Latin America. The campaign fought successfully for access to a state-issued driver's licence for people who could not produce proof of lawful presence in the USA. Far from focusing overtly on the "meanings and expressions of citizenship," this effort was initiated by and designed to benefit a population of non-citizens. Moreover, at least in its public aspect and public rhetorical strategies, it seldom mentioned anything remotely like "rights." Nonetheless, the campaign and its aftermath should be of interest to those who believe that traditional ideas about citizenship and its attendant rights and duties need to be re-imagined for a global age.

The presence of low-wage Southern immigrants in the wealthy countries of the North creates a space where the contradictions of uneven development are 
manifested in a particularly striking way; this space offers important learning opportunities for students of citizenship. Efforts like these, where transnational migrants attempt to improve their material and legal standing, occur at a site where traditional ideas of national or territorial citizenship come into particularly sharp confrontation with the new dynamics of accelerating globalization. Since they are being initiated by some of the people most directly and adversely affected by global dynamics, these efforts provide an opportunity for scholars to listen to how such people perceive and define the unprecedented problems they face, and to see what kinds of solutions they have begun to propose. Sometimes the most interesting of such efforts will be those that are just emerging and least shaped into demands that fit existing templates.

Another reason these pro-immigrant campaigns are valuable and worthy of study is that they pose important questions about who in the global economy has the "right to have rights" in the first place. They press more of the native-born to consider the exclusionary, "fortress" side of Northern citizenship in today's world.

The first section of the article will provide some historical and factual backdrop for the Tennessee campaign. The second section will sketch some highlights of the campaign itself —or rather, of the campaign up to summer 2003, since the story is far from over. The third section will offer some reflections and tentative conclusions.

\section{Background}

\section{Historical boundaries of U.S. citizenship}

Citizenship means many things, of course. Sometimes it signifies a formal, legal status, and, at other times, a substantive set of citizenly obligations and rights. Both of these meanings have been at the centre of past struggles for social justice in America, movements whose successes and failures alike have profoundly affected the nation's history and character.

The question of citizenship as formal legal status was a major theme during the fight to abolish and dismantle slavery, and in the process of resolving the status of peoples taken over in expansionist moments of U.S. history. In the infamous 1856 Dred Scott case, for instance, the U.S. Supreme Court ruled that American blacks "are not included, and were not intended to be included, under the word 'citizens' in the Constitution, and can therefore claim none of the rights and privileges which that instrument provides for and secures to citizens of the United States.” ${ }^{2}$. It took a prolonged period of legal and extra-legal struggle before American black people won their freedom and formal citizenship under an amended constitution, and the twentieth century was half over before the basic political and civil rights of AfricanAmericans were recognized or enforced in any serious way (Bell, 2000; Foner, 1988). American Indians and Puerto Ricans are only two of many groups that have been subsumed under formal U.S. control, but whose relation to status citizenship has been circuitous and uneven (Prucha, 1986; Roman, 1997).

Other great arenas for contestation about status citizenship in America have been immigration and naturalization (Saito, 1997). For example, the right to become a naturalized citizen was limited by federal law to "white persons" in the Naturalization Act of 1790, a restriction not formally repealed until the mid- 
twentieth century (Lopez, 1996). Similarly, the right to immigrate (a predicate to any later naturalization) has been subject to a long train of overtly race-based restrictions, stretching from the Chinese Exclusion Act of 1882 through to the national quota systems that were not finally abolished until 1965 (Neuman, 1996). Those targeted by these exclusions did what they could to oppose them, but successes were limited (McClain, 1994; Rosales, 1999). To the present day, the Supreme Court remains highly deferential toward legislative action by the U.S. Congress in this area. The Court takes the position that Congress has "plenary power" over immigration and naturalization questions, and its exercise should not be subjected to the same standards of judicial review that the Court would apply in almost any other context (Motomura, 1990; Wu, 1996).

Of course, much social justice work in the USA has focused on the proper substance of the rights to be enjoyed by citizens, not on the formal criteria for who was eligible to be one. Organizations and citizens' movements have worked to deepen the substance of the citizenship rights accorded to groups that have been subjected to subordinating or marginalizing practices of different kinds. In good times, they have fought for more expansive understandings about things that all citizens should be able to expect from the state and from each other, and in bad times they have defended what rights they had against incursions by public and private power. While these struggles over the substance of citizenship went forward, the categories and divisions associated with outsiders' access to the status of citizenship continued, although often at the margins of mainstream national consciousness.

\section{Present context}

Today we are in a period when the status of citizenship in the USA - the line between citizen and non-citizen - is back in the spotlight, and given the turbulent global conditions that presently prevail, the task of drawing and justifying such a line is likely to prove difficult in ways not felt before. A vibrant if embattled network of new groups has emerged, and older organizations have also begun to see that lowwage immigration presents both in opportunity and an imperative for those interested in organizing for justice (Delgado, 1993; Milkman, 2000). Meanwhile, working for immigrants' rights has become more difficult but also more important in the atmosphere that gripped the nation after September 11, 2001 (Lawyers Committee for Human Rights, 2002; 2003). The campaign to win and then to defend immigrant access to the driver's licence in Tennessee is a case in point.

Agriculture originally dominated the Tennessee economy, but in more recent times, agriculture has been complemented and partly supplanted by a strong industrial sector concentrated largely in low-wage industries like garments, textiles and consumer electronics. Many manufacturing firms first moved to Tennessee from further north in search of the low wages, docile and unorganized workers and "business friendly" regulatory environment for which the southeast has long been known. Today, Tennessee is experiencing trends familiar elsewhere: agriculture is increasingly mechanized and concentrated in ever fewer hands; manufacturing is in rapid decline; the service sector is on the rise; and the proportion of the workforce that is organized into labour unions is steadily slipping. 
While many manufacturing jobs have moved to lower-wage locations in Mexico and elsewhere, mass in-migration and settlement of low-wage Latina and Latino workers has emerged as a major demographic phenomenon (Lowell \& Suro, 2002). ${ }^{3}$ New arrivals from the global South have been entering and transforming both labour markets and the texture of daily life in many communities, large and small (Fink, 2003). In Tennessee, the overall number of Latinas and Latinos is still a relatively small percentage of the population, but they are nonetheless a striking new presence. In some counties, the growth has been especially dramatic, with attendant impacts on schools and other institutions that are ill-prepared to cope equitably or competently with the newcomers they are now challenged to serve (Mendoza, 2002; Smith, 2001).

I teach at a Tennessee law school, where post-baccalaureate students prepare for professional practice. In the course of my research and service with local community groups, ${ }^{4}$ and while supervising students in field placements, I became interested in Latina and Latino newcomers. My students and I began searching out opportunities to talk with immigrants about their experiences with the legal system and about their need for legal services.

As we made contact, over and over we heard the same refrain. Three main concerns predominated and the three were closely related. ${ }^{5}$ First the immigrants we spoke with wanted to understand their rights (or lack thereof) in situations where they were stopped or arrested by the police. Second, they wanted to know the circumstances under which such a stop or arrest might lead to an entanglement with the immigration authorities. Third, they wanted to tell us about the impossibility of getting a driver's licence, and to explain to us what a huge impact that was having on their lives. We learned that the law in Tennessee had recently changed, so that applicants for a licence now had to provide a social security number. (Only persons who are authorized to work in the USA are assigned such a number, and for the most part this means citizens and those who have been granted Legal Permanent Residency status, with its accompanying "green card.") The new law effectively barred undocumented immigrants from obtaining a licence to drive.

Such a bar was significant in ways that may be difficult for non-US readers to appreciate. In Tennessee, as in many other U.S. locations, there is basically no local public transportation outside the tight central core of the larger cities. For the vast majority of people, including poor people, an automobile is a virtual necessity for even the simplest acts of daily existence, including the task of getting to and from one's place of work. Our informants were eager to explain how the pieces of this situation fitted together into an oppressive whole that greatly magnified their vulnerability:

- All undocumented people were prohibited from getting a Tennessee driver's licence

- A significant percentage of the Latina/Latino community in Tennessee was undocumented

- The chances that any given person found "driving while brown" would also be driving without a licence were therefore astronomically increased

The simple probabilities produced by these facts could not possibly escape the notice of law enforcement officials. Under the circumstances, it seemed that the 
temptation for a police officer to engage in racial profiling would be almost irresistible, whether they were interested in oppressing and harassing Latinas and Latinos, hustling a personal bribe or simply enforcing the law about driving without a licence. Stories confirming the frequency of such profiling were common fare in these conversations. It seemed that any Latino then at the wheel of a car in Tennessee both felt, and was, a target for police attention abuse or both.

Upon hearing these stories in the field, the black law students on my courses found it easier than the white students to identify with the apprehension expressed by immigrants toward the police. They also could better imagine the stress induced by the need for constant vigilance. But all of us, black and white alike, found it bizarre to think that at the conclusion of one of our discussion sessions-at some venue such as the prosaic fluorescent-lit and linoleum-floored fellowship hall of the local Catholic church, for instance-one group of us would get into our automobiles and return to our homes routinely, with little or no apprehension that a police stop might change our lives. Meanwhile, another group would drive home as though players in some suspense-filled war movie about life under military occupation, eyes peeled for each police cruiser, stomachs jumpy with the knowledge that any random road block might spell economic and family disaster.

\section{The campaign}

As we came to find out, we were not the only people in Tennessee who were hearing these kinds of stories. A growing population of native-born people was developing an awareness about the existence and the situation of undocumented people. Many had become staunch supporters of the immigrant community and its right to live unmolested, and many appeared to be itching for something they could do about what they saw as harsh injustice. Not a single immigrants' rights organization was yet in existence in the state, however: no informal network, list of statewide contacts, phone tree, system of referrals. There were smaller networks where new knowledge about immigrants was starting to circulate, and were people were beginning to discuss issues, compare notes and express outrage. In the spring of 2001, the drivers' licence campaign provided the seed around which these emerging trends and networks could crystallize.

An ad hoc statewide coalition emerged, drawing support from a broad range of likely and unlikely bedfellows. A website and e-mail lists were created, and the Tennessee campaign took advantage of then-nascent national network that had identified the issue of the driver's licence as one that was worth the time of immigrants' rights. In amazingly short order, the new coalition managed to put together a legislative campaign, move a bill through the general assembly, and secure the Republican governor's signature. The programme was implemented, and soon licences were being issued once again to undocumented immigrants in Tennessee. Within days, throngs of Latinas and Latinos descended on licensing stations. Native-born people, who had not paid that much attention to immigration dynamics, got quite a jolt if they happened to show up to get their licence during that period. But the initial bottlenecks soon passed, and a new normalcy appeared to have taken hold. 
Many people involved in the effort, myself included, admitted to being somewhat dumbfounded at the campaign's success. Several had been dubious about the prospects of securing this reform, especially given the conservative tenor of the Tennessee legislature and the reservoirs of anti-immigrant feeling that advocates had reason to believe existed in the state. The concerns of these doubters were not illfounded. For instance, anti-immigrant groups in the state scrambled to respond to our campaign, and soon after the bill's passage launched a repeal effort. Then when the World Trade Center was attacked a few short months later, the impacts were wide and deep. Anger and fear among the native-born were epidemic, and immigrants of all kinds became the objects of widespread fear and suspicion.

Despite the post-9/11 climate, the pro-immigrant forces in Tennessee have succeeded so far in maintaining immigrant access to the driver's licence. However, access is now more burdened, in that people without a social security number have that fact flagged on the front of their licences. Nevertheless, our initial success, and our ability to resist full-scale repeal after 9/11, represent important victories. Several factors helped to secure them.

Perhaps the most basic contribution is that Latina and Latino immigrants themselves, together with their transnational family and friendship networks, laid the basic foundation, without which nothing would have been possible. The mass migration from Latin America to the USA is itself quite a multi-generational feat of human adventure and engineering, and it has been accomplished against stiff odds and despite sometimes intense repression, intimidation and harassment. ${ }^{6}$ Once here, these legions of low-wage immigrants have built relationships and "proved" themselves in-ways that contain plenty of irony and ambiguity, but in any event have created a multitude of potential patrons and allies.

Second, we succeeded (to the limited and still unstable extent that we did) because the time was right. In many communities, the Latino population had reached sufficient critical mass to create free spaces for communication and planning -in places like Latino groceries, Hispanic church services, scattered radio stations and small newspapers around the state. Meanwhile, among the native-born population, the anti-immigrant forces were still relatively quiescent, but pro-immigrant individuals and emergent networks were ready and eager to sink their teeth into a concrete project. As a result, when we organized visits to the state legislature in Nashville and made our calls to legislative offices, our side represented the vast majority of contacts the legislators were receiving.

Third, we learned that support for immigrants can come from unexpected quarters. Agricultural employers, the Nashville Chamber of Commerce and the police chiefs of several major cities were on our side, in addition to more accustomed allies like church groups, service providers, civil rights organizations, labour unions and social justice groups. These unusual bedfellows had political clout, and they offered cover for legislators that the "human rights types" could never have mustered alone. The eagerness of the Republican Party to establish ties to the Latino community undoubtedly had some influence on the outcome, increasing the willingness of our Republican governor to sign the bill into law, and later to defend it from full repeal.

A final reason I believe we won this struggle for the rights of undocumented workers in Tennessee is that we did not frame the campaign as a struggle for rights at all. Instead, at least in its visible, public face, the campaign was framed almost entirely around the desires, interests and preferences of U.S. citizens. For instance, 
the ad hoc group that we created to push the reform was called "Health and Safety for Tennessee Highways.” That group developed talking points that stressed things like the value of having these potentially dangerous Latino drivers properly trained, tested, licenced and insured. It also pointed out that if undocumented immigrants possessed a driver's licence, they could be tracked down more easily by police. The central messages developed by organizers focused on the training, testing and insurability of immigrant drivers, on disruptions to local business and commerce, and on the cost to the state government of forgoing licence-related fees paid by immigrants and of volunteering to shoulder the duties of federal immigration law enforcement.

The choice of a frame that left immigrants themselves so decidedly in the shadows was not uncontroversial within the campaign, but it represented a clear majority of opinion among those who developed the strategy. Certainly, the highway safety issues were not trumped up. The statistics about deaths and injuries in car crashes involving Latina and Latino immigrant motorists are alarming, and the number of people - native-born and immigrant alike-who drive uninsured in Tennessee is a scandal. Nevertheless, most people who threw themselves into our campaign did not come to it out of an involvement in issues of highway safety, but because of a strong concern for immigrants' needs and rights. The decision to frame the issue as one of highway safety grew out of the organizers' conviction that putting immigrants' rights or their welfare at the centre of the campaign (or even out toward its margins, if openly expressed) would be the kiss of death. Although I was among those who questioned this decision, in retrospect I believe we probably would have lost the campaign had we pursued a more rights-oriented or immigrant-centred approach.

For all those involved, the decision was made easier by our knowledge of the acute difference that this particular concrete reform could make in the lives of people we knew. It would magnify freedom and decrease terror for sizeable numbers of people we knew and cared for. It seemed that success on this issue would be an educational and confidence-building win for the immigrant community, even if the framing and the official rhetoric deployed in the campaign pretty thoroughly ignored the issue of justice for immigrants.

Of course, the dilemma we faced was hardly unique. Most legislative campaigns involve trade-offs and choices about long-term goals and short-term realities. Efforts at organizing relatively powerless people from below will always have to wrestle with how much to highlight the rights or needs of the weak, and how much to appeal to the self-interest of the strong - including potential allies who have more resources and clout, as well as the decision-makers themselves. Legislative campaigns that aim to benefit undocumented immigrants are especially likely to raise these questions because such campaigns are situated at the fault-line over who should have even the "right to have rights." After all, undocumented immigrants cannot vote, and are therefore not part of the constituency to which an elected legislator owes formal accountability. Further, significant numbers of the people who are part of the legislator's formal constituency are likely to view the concerns and wellbeing of non-citizens as an illegitimate object of their representative's concern.

Nevertheless, within and beneath this "non-rights campaign," many issues of rights, justice and morality did indeed emerge. Individual campaigners with whom I have spoken echoed my own experience that actual conversations often led us naturally beyond the official theme of safety and security for native Tennesseans, 
and provided openings — some small and subtle, others more generous and clear-for telling other kinds of stories, and pressing other kinds of arguments. In fact, no matter what the public rhetoric on either side, everyone understood that beneath the announced issues lay a mass of other questions that profoundly challenged the current immigration regime. In any case, once the anti-immigrant organizations began to get themselves in gear, there was no way entirely to ignore the issues of immigration policy, even if the campaign had been unambivalent in wanting to do just that.

So in the end, this last ingredient of our success is something of a paradox. We did create and stick with a credible public frame that spoke to citizens and legislators about their own self-interest, and I believe that probably contributed to the success of the campaign. At the same time, the choice of this public frame was not as narrowing or chauvinistic as it may sound, because in actuality it did not banish more immigrant-centred conversations and frames from playing an important role in the life of the campaign. Sometimes by choice and sometimes by necessity, the campaign did create a space for public debate and dialogue with native-born Tennesseans about the immigrant community that has grown up in our midst, and about the justice or injustice of its circumstances.

In fact the campaign's role as the start of something bigger may be the most important point to make here. In preparation for this article, I contacted a number of people who had been active in the 2001 campaign and asked them for their present thoughts. All of them were pleased and proud of the victory that was won, but also acutely aware of its continuing fragility. Each remarked with amazement how gratifying it had been to participate in something that created such a dramatic, concrete change for the better in the lives of so many vulnerable people. On one final point they were particularly vocal. The best thing about the campaign, they said, was that it enabled immigrants and their supporters around the state to find each other and to begin building longer-term relationships and collaborations.

Tennessee is now home to a formal organization, the Tennessee Immigrant and Refugee Rights Coalition. It has a budget and a (very modestly) paid staff, and it holds regular state-wide meetings. The Coalition continues to be involved in the question of the driver's licence, but its agenda is now much broader and it speaks out regularly on many issues of concern to immigrants and refugees. These days, more meetings are conducted in Spanish, ${ }^{7}$ and more leadership roles are filled by immigrants and refugees themselves than in the early days of the campaign, when most of the co-ordination was provided by citizen allies rather than by immigrants themselves. The challenges that lie ahead are serious ones, but networks and relationships among people interested in fighting for immigrants' rights are substantially ahead of where they were when the driver's licence campaign began.

\section{Meanings and expressions of citizenship}

The final section of this article will step back from the immediate facts of the driver's licence campaign, to ask what lessons we might take from it about the meanings and expressions of citizenship. I am interested in building knowledge that can be put to use by scholars and activists who want to help mount democratic, bottom-up challenges to social exclusion and injustice. 
The discussion here will assume that ideas of "citizenship" and of "rights" are neither good nor bad in themselves. Although the concept of citizenship and the rights attendant to it may offer helpful resources for winning a more democratic, open and sustainable order (Johnston, 2002; Mouffe, 1992; 1993), it sometimes can and has been used for very different ends. So my question is not whether rightsbased approaches associated with citizenship can be useful to the project I have named, but rather when, how, and under what circumstances they are most likely to be useful-or not.

The Tennessee driver's licence campaign is a paradoxical but significant site for studying rights and citizenship. It was part of a wider mobilization that continues today in the USA; one in which undocumented immigrants - people with no standing as U.S. citizens or even as legal residents-are "making a way out of no way,"8 offering the rest of us much-needed windows on to the global landscape, demonstrating new models, and inviting us to reinvent our own citizenship (Hair, 2001; Smith \& Sugimori, 2003).

In many instances, those involved in this mobilization are not claiming formal legal rights, because in the context at hand they cannot point to any officially recognized rights that are available for them to claim. To be sure, there are some justiciable protections, constitutional and otherwise, that apply to immigrants in the USA (Chin, Romero \& Scaperlanda, 2000). Further, a number of immigrants' rights groups are attempting to win new, formally recognized rights for immigrants in specific contexts, such as access to higher education, and broader regularization of guest workers in agriculture. Nevertheless, much of the activity pursued on behalf of immigrant welfare is pursued by necessity in a landscape of "no rights."

One might characterize the larger context for these campaigns as a large-scale, decentralized social experiment that combines diverse elements, including:

- The mass migration itself, which can in some ways be best appreciated as a kind of collective civil disobedience

- Political mobilizations and community and labour organizing efforts carried out with various allies (including communities of native-born and naturalized Latinas and Latinos in some regions of the country, as well as church groups, civil rights organizations and labour unions) ${ }^{9}$

- The building of social and economic capital through a thicket of relationships and channels that are fusing immigrants into society in ways that already appear impossible ever to undo.

The loose national network of driver's licence campaigns across the USA provides a vivid example of the still-emergent, still-inchoate work of building new claims suited to our new global economy. Sometimes such claims are based on formally realizable rights; at others they may only hint toward a possible future. Sometimes, instead of invoking rights, campaigns speak forcefully of needs, or of higher principles beyond existing domestic or international norms, or of the self-interest of those in a position to grant rights or mere concessions.

In any case, these campaigns provide spaces where immigrants are objecting to their exclusion from the licensing system, telling stories about what it means to lack a formal "identity" sufficient to grant access to the normal workings of the national economy in which one labours. Such campaigns allow immigrants to describe in 
arresting detail the irrationality and strain of their situation: thoroughly integrated into the mundane workings of the aboveground economy, and at the same time legally excluded, forced to traverse daily an uneven and unpredictable minefield of simultaneous normalcy and criminality. In providing the rest of us with these narratives, immigrants help themselves and us to imagine the human rights we need for our new global condition,

There is no assurance that all immigrants' rights movements in the USA will smoothly advance toward stronger rights, or that they will develop in ways that challenge rather than sustain existing power relations. But current campaigns for access to the driver's licence are one part of a pre-legal, pre-institutional process that is helping to incubate novel rights claims appropriate for the new economy. In what follows I will sketch three citizenship norms that may be prefigured in current discussions and dialogue growing out of these concrete struggles.

\section{The full right to international mobility of human beings}

A full right to human mobility across international borders is a radical idea, one whose realization would require a direct assault on the notion that the unfettered authority to exclude non-citizens is an essential feature of national sovereignty. (Even the United Nations's International Convention on the Protection of the Rights of All Migrant Workers and Members of Their Families, which entered into force in 2003 and is a welcome new development, only guarantees international mobility as the right to leave any state, plus the right to return to one's country of origin.) In the U.S. context, full international mobility would also require a confrontation with deep patterns of white racial privilege that run through the nation's legal and social history.

Nevertheless, the idea of radically more open borders has proved to be a difficult claim for wealthy states entirely to shake off; in part because it points up the sharp contradiction embedded in free trade regimes such as the North American Free Trade Agreement (NAFTA) that force signatory states to submit to the free flow of goods, capital and services but do not similarly protect the free flow of people. Whether despite or because of its unsettling implications, the call for open borders seems always just beneath the surface of every conversation on immigration. It appears simultaneously to be the only logical solution and-at least at present-a political impossibility.

\section{The right to identity}

Another emergent claim of right that may be gestating in the driver's licence campaign is a "right to identity"- something like a transnational right to recognition of a migrating person's identity and origin. In today's high-tech world, this would include a right of entry into the computerized identity systems that exist at a national and sub-national level all over the world, but most hegemonically in core countries. Undocumented immigrants teach us that the lack of capacity to identify oneself in the information economy can be a devastating disability. Immigrants in the USA want a driver's licence first and foremost so they can engage in daily travel with less 
vulnerability. But many of them also want such a licence because it serves as a general identity document, needed nowadays for everything from renting a video to flying back home for a parent's funeral.

A U.S. social security number is generally available only to citizens or legal permanent residents. In recent years, its uses have expanded, and it is now demanded for an increasing range of public and private transactions and background checks. Undocumented immigrants are by definition excluded from access to this powerful number, and yet they encounter multitudinous situations where proof of identity is required. Accordingly, both from immigrants themselves and from those who have dealings with them, the pressure for some method of identification has become intense.

Troubling questions surround the notion of a right to identity like the one sketched here. How would such a right relate to the emerging U.S. security state and its powerful new information technologies? Surely there is some irony in the idea of vulnerable people clamouring for admittance to a computerized system that will subject them to more efficient surveillance by a hostile and powerful foreign state. Given the dramatic erosion of the rights and liberties of both citizens and noncitizens that has accompanied the Bush administration's announced war on terrorism, the cost of being integrated into state licensing systems warrants thoughtful deliberation. Still, the cost of not being included is also demonstrably high, as we learned from immigrant narratives in Tennessee. This dilemma about the costs of entry into information systems mirrors similar painful choices about global economic integration that presently confront poor people and poor countries around the world.

\section{Duties of citizenship in a globalizing world}

If immigrants' rights activism in countries of the North provides a hospitable environment for imagining and incubating new rights, these settings may also provide important laboratories for discerning the duties that should attend new conditions of global economic integration.

Some duties suggested by the situation of transnational low-wage workers make up the duties of the powerful. As many have argued, in a just legal order the shape of both rights and duties would be determined with pointed reference to power relations and would be designed to reduce and repair illegitimate disparities. With superpowers, they imply, should come super-responsibilities (Matsuda, 1991; Stammers, 1999). For instance, given the role that the USA has played in shaping and constraining the economies of most countries in the world, perhaps it should recognize a specifically American duty to admit many more economic refugees for secure and dignified employment in the USA. However, although pre-eminent, the USA is not alone in its disproportionate influence on the fate of other countries. Perhaps all the nations of the global North should take on co-ordinated duties of admission, keyed to their respective powers and histories. History-conscious, postcolonial immigration practices by some European states offer imperfect models for thinking about how such duties might be framed.

The facts of immigrants' lives also suggest that duties toward trans-national migrants do not reside with states alone. Exercises of private power can affect labour migration as greatly as do exercises of state power. Accordingly, both the pushes and 
the pulls that affect global migrant streams point to other duty-bearers, such as multinational corporations, international financial institutions and the public/private machineries that create, embody and administer international trade agreements.

Immigrants' rights struggles also require citizens of the North to think about their own duties as persons who are in a position of relative privilege as compared to citizens of poorer countries. To be sure, workers and low-income people in the USA have many interests that are significantly aligned or at least overlapping with those of workers in other countries. But even they enjoy privileges and powers whose parameters they are seldom able to appreciate without the perspective added by looking through the eyes of others. The cauldron of immigrants' rights struggles provides one place where First World citizens can begin to discern something more about their privileges and the duties they should imply.

Speculation about pockets of immigrant activism helping to incubate not only new global rights but also new "duties of global solidarity," takes me far beyond the Tennessee campaign for the driver's licence. As someone who learned much from being a participant observer in the one small campaign described here, I can say with confidence that many native-born citizens who become involved with immigrantsin fights that range from the mundane to the sublime-have been profoundly changed by the experience. For the most part, Americans have precious little knowledge of our own nation's immigration law, few experiences that help us understand the role our government and corporations play abroad, little familiarity with international institutions that our government dominates, and only the thinnest exposure to cultures and languages other than our own. The driver's licence tight gave many Tennesseans a chance to start knowing more about these things and to consider our own responsibilities as citizens of a thoroughly fractured and connected world.

\section{Notes}

1 This article was originally published as a chapter in Inclusive Citizenship: Meanings and Expressions, Naila Kabeer, ed. London: Zed Books 2005, pp. 199-215.

2 Dred Scott v. Sandford, 60 U.S. 393, 404 (1856).

3 Demographics are intently watched in the USA, given their relationship to racial politics. The U.S. Census reported that the U.S. Hispanic population grew by 57.9 per cent between 1990 and 2000, as compared with 13.2 per cent for the population as a whole. Over half were of Mexican origin (Guzman 2001).

4 For more background on this research, on my organizational collaborator (the Tennessee Industrial Renewal Network, now renamed the Tennessee Economic Renewal Network), and on my experiences as a participant observer in some of the organization's work, see Ansley (2001); TIRN (1993).

5 The issues centred on the concerns of undocumented people, so it may be worth pointing out that many of the people we spoke to in this information-gathering process were 'legal'; that is, many of them were lawfully present in the USA and also entitled to work, because they were birthright citizens or naturalized citizens, or because they had been granted Legal Permanent Resident status, which entitled them to a (non-green) "green card" and a social security number. But all of them, legal or not, made it clear that the concerns of the undocumented were questions of the highest priority. The vast majority, even if they were lawfully present themselves, had family members or close friends who were undocumented. In any case, the operating assumption seemed to be that the treatment accorded to undocumented immigrants directly affected all other members of the Latino community. 
6 I do not mean to suggest that all Latina/ Latino immigrants to the USA consider themselves to be part of a social movement for rights or any other organized social project. Latino immigrants are an extremely diverse group. They come to the USA with many different goals; they subscribe to many different ideologies and dreams; they bring with them many different levels of resources; and they are changed in many different ways after they arrive.

7 The Coalition's membership is not limited to English and Spanish speakers, nor is it limited to issues of concern to the Latina/Latino community. There are active participants from Africa, the Middle East, Asia and Eastern Europe, and their issues are prominent on the agenda of the Coalition. Nevertheless, Spanish is by far the most numerically significant minority language spoken in the Coalition and in the state.

8 This lovely phrase is one passed on by American labour and civil rights historian Michael Honey (1999, p. 86).

9 Recently, the American Federation of Labor and Congress of Industrial Organizations (AFL-CIO), the nation's largest labour federation, announced a sharp reversal of its previous restrictive position on immigration. Now, the federation and many of its union affiliates are campaigning for broader legalization programmes and are actively recruiting among immigrant workers (Nissen, 2002). Of course, many difficulties and questions about the future of organized labour and its relationship to immigrant workers remain.

\section{References}

Ansley, F. (2001). Inclusive boundaries and other (im)possible paths toward community development in a global world. University of Pennsylvania Law Review, 150, 353-417.

Bell, D. (2000). Race, races and American law (4th edition). New York, NY: Aspen Publishers.

Chin, G., Romero, V., \& Scaperlanda, M. (Eds.) (2000). Immigration and the constitution: Origins of constitutional immigration law. New York \& London: Garland Publishing.

Delgado, H. (1993). New immigrants, old unions: Organizing undocumented workers in Los Angeles. Philadelphia: Temple University Press.

Dred Scott v. Sandford. 60 U.S. 393: 404 (1856).

Fink, L. (2003). The Maya of Morganton: Work and community in the Nuevo New South. Chapel Hill, NC: University of North Carolina Press.

Foner, E. (1988). Reconstruction: America’s unfinished revolution, 1863-1877. New York, NY: Harper \& Row.

Guzman, B. (2001). The Hispanic population. Census 2000 Brief. Washington, DC: U.S. Bureau of the Census.

Hair, P. (2001). Louder than words: Lawyers, communities and the struggle for justice. New York, NY: Rockefeller Foundation.

Honey, M. K. (1999). Black workers remember: An oral history of segregation, unionism, and the freedom struggle. Berkeley, Los Angeles \& London: University of California Press.

Johnston, P. (2002). Citizenship movement unionism: For the defense of local communities in the global age. In B. Nissen (Ed.), Unions in a globalized environment: Changing borders, organizational boundaries and social roles. Armonk, NY: M. E. Sharpe.

Lawyers Committee for Human Rights (2002). A year if loss: Re-examining civil liberties since September 11. New York: Lawyers Committee for Human Rights (available online at www.lchr.org).

Lawyers Committee for Human Rights (2003). Imbalance $j$ powers: How changes to us law ex policy since 9/11 erode human rights and civil liberties, September 2002-2003. New York, NY: Lawyers Committee for Human Rights (available online at www.lchr.org).

Lopez, I. H. (1996). White by law: The legal construction of race. New York: New York University Press.

Lowell, B. L. \& R. Suro (2002). How many undocumented: The numbers behind the US-Mexico migration talks. Washington, DC: Pew Hispanic Center.

McClain, C. J. (1994). In search of equality: The Chinese struggle against discrimination in nineteenthcentury America. Berkeley, CA: University of California Press.

Matsuda, M. (1991). Voices of America: Accent, antidiscrimination law, and a jurisprudence for the last reconstruction. Yale Law Journal, 100, 1329-1404.

Mendoza, M. (2002). Latino immigrant women in Memphis. Memphis, TN: Center for Research on Women. 


\section{Fran Ansley}

Milkman, R. (2000). Organizing immigrants: The challenge for unions in contemporary California. Ithaca and London: Cornell University Press.

Motomura, H. (1990). Immigration law after a century of plenary power: Phantom constitutional norms and statutory interpretation. In G. Chin, V. Romero \& M. Scaperlanda (Eds.) (2000) Immigration and the constitution: Origins a of constitutional immigration law (pp. 285-613). New York \& London: Garland Publishing.

Mouffe, C. (Ed.). (1992). Dimensions of radical democracy: Pluralism, citizenship, community. London \& New York: Verso.

Mouffe, C. (1993). The Return of the political. London \& New York: Verso.

Neuman, G. (1996). Strangers to the constitution: Immigrants, borders and fundamental law. Princeton, NJ: Princeton University Press.

Nissen, B. (Ed.) (2002). Unions in a globalized environment: Changing borders, organizational boundaries and social roles. Armonk, NY: M. E. Sharpe.

Prucha, F. P. (1986). The great father: The United States government and the American Indians. Lincoln, NB: University of Nebraska Press.

Roman, E. (1997). Empire forgotten: The United States colonization of Puerto Rico. Villanova Law Review, 42, 1119-1211.

Rosales, F. A. (1999). Pobre Raza!: Violence, justice and mobilization among México Lindo immigrants, 1900-1936. Austin, TX: University of Texas Press.

Saito, N. T. (1997). Alien and non-alien alike: Citizenship, "foreignness" and racial hierarchy in American law. Oregon Law Review, 76, 261-345.

Smith, B. E. (2001). The new Latino South: An introduction. Memphis: Center for Research on Women.

Smith, R. \& Sugimori, A. (2003). Low pay, high risk: State models for advancing immigrants' rights. New York, NY: National Employment Law Project.

Stammers, N. (1999). Social movements and the social construction of human rights. Human Rights Quarterly, 21, 980-1008.

TIRN (1993). From the mountains to the Maquiladoras [Video]. Knoxville, TN: Tennessee Industrial Renewal Network.

Wu, F. (1996). A moderate proposal for immigration reform. In G. Chin, V. Romero \& M. Scaperlanda (Eds.) (2000) Immigration and the constitution: Origins of constitutional immigration law (pp. 61-100). New York \& London: Garland Publishing. 